\title{
CONGRESSIONAL POWER UNDER THE CIVIL WAR AMENDMENTS
}

\begin{abstract}
Since their birth during Reconstruction, the thirteenth. fourteenth and fifteenth amendments have been the subject of heated conmentary and varying judicial interpretations. During the 1965term and more recently, in 1968. the Supreme Court, in several landmark decisions, has expansively described the power granted Congress by those provisions to safeguard civil liberties. This comment exanines these decisions from the perspective of early. judicial interpretation of the amendments and from the theories offered by modern constitutional scholars. In conclusion. the logical results of this almost unrestricted measure of congressional power are examined.
\end{abstract}

Jones $v$. Alfred $H$. Mayer Co.' no doubt came as a great surprise to most laymen and to many practitioners who marked it, among other things, as a rather eccentric resurrection of an ancient statute 2 in order to deal with a very current problem. The foundation for the holding, however, had been laid in 1966 with three major decisions ${ }^{3}$ which put observers on notice that Congress would be allowed to exercise its constitutionally delegated powers in the area of civil rights with a minimum of judicial interference. The 1966 decisions can be characterized as a passing of the torch in civil liberties protection from the judiciary, where it had rested quite firmly since 1954, to the Congress, whose powers were now to be allowed to reach their fullest potential under the constitutional authority of the enforcement sections of the Civil War amendments. ${ }^{4}$

The express powers of Congress in the area of human rights had

392 U.S. 409 (1968). For examples of the reaction to Alfred Mayer, compare Casper, Jones v. Mayer: Clio, Bemused and Confused Muse, 1968 Sup. CT. REv. 89 and Ervin, Jones v. Alfred H. Mayer Co.: Judicial Activism Run Riot, 22 VAND. L. REv. 485 (1969) with Kinoy, Jones v. Alfred H. Mayer Co.: An Historic Step Forward, 22 VAND. L. Rev. 475 (1969 and Kohl, The Civil Rights Act of 1866. Its Hour Come Round At Last: Jones v. Alfred H. Mayer Co., 55 VA. L. REv. 272 (1969).

242 U.S.C. § 1982 (1964) (originally enacted as Act of April 9, 1866, ch. 31, § 1, 14 Stat. 27). See notes 114-17 infra and accompanying text.

see notes 10-13 infra and accompanying text.

'U.S. Const. amend. XIII, § 2; U.S. Const. amend. XIV, § 5; U.S. Const. amend. $X V, \S 2$. With some insignificant variation in syntax, these sections each provide with reference to their particular amendment, "Congress shall have power to enforce this article by appropriate legisiation." 
long lain in complete disuse following several critical blows dealt to the enforcement sections by the Supreme Court during the first few decades after the adoption of the Civil War amendments. ${ }^{5}$ Congress subsequently desisted in its initial attempts to overcome judicial hostility to civil rights legislation not out of temerity but because of growing disinterest in the welfare of the freedman. ${ }^{6}$ It finally became clear that the first movement toward effective civil and minority rights protection ironically had to be taken by the judiciary, the same branch which earlier had emasculated all similar legislative attempts at implementation of the demands of the thirteenth, fourteenth, and fifteenth amendments. ${ }^{7}$

Whatever the sociological and political reasons, the renewed concern for human rights did not long remain unique with the Warren Court. The minority rights movement had become a sufficiently popular cause to require attention from the national government in its executive and legislative, as well as judicial, capacities. The response was a rejuvenated effort to write legislation establishing standards and remedies for civil rights protection. ${ }^{8}$ It was soon apparent that Congress, aided by the executive branch's enforcement machinery, was far better equipped than the Supreme Court to carry forward the burdens of these undertakings. Judicial reaction to the congressional response manifested itself in 1966, this time with an effort to underpin the legislative activity with constitutional authority. Since the Commerce Clause was not perfectly adaptive to the occasion-and was especially susceptible to the criticism of being a disingenuous device - the ans wer was found in the previously neglected enforcement sections of the Civil War amendments.

Understood in their broadest terms, three decisions of the Supreme Court have achieved the goal of discerning constitutional

\footnotetext{
${ }^{5}$ See text accompanying notes 35-98 infra.

- The Civil Rights Act of 1875 , Sess. 11, ch. 114, 18 Stat. 335, was the last major piece of civil rights legislation until the enactment of the Civil Rights Act of 1957.71 Stat. 634 (codified in scattered sections of 5, 28, 42 U.S.C. (1964)).

'This comment will not endeavor to review the efforts of the Supreme Court to breathe new life into the inflexible concept of "state action." The subject has been adequately covered elsewhere by many scholars. The development which these decisions and critiques describe, however. can be fruitfully compared with the present exercise in order to appreciate the potential of congressional power against the background of the limited notion of judicially identified state action.
}

"See note 102 infra.

'See Cox, The Supreme Court 1965 Term, 80 HARv. L. REv. 91 (1966). 
sanction for the new legislation and perhaps much more. On the strength of section 2 of the fifteenth amendment, Congress was given wide latitude in the case of South Carolina v. Katzen bach ${ }^{10}$ in identifying and proscribing evils in voting discrimination. Katzenbach $v$. Morgan ${ }^{11}$ found conferred upon Congress broad power under section 5 of the fourteenth amendment to define standards of "equal protection of the laws."12 In United States $v$. Gues $t^{13}$ that same section raised the possibility of reaching ostensibly private acts of discrimination, thus introducing a radically new understanding of the old concept of state action. ${ }^{14}$ Against this background Alfred Mayer should have caused little surprise when the Supreme Court completed the mandate to Congress by permitting legislative definition of "badges of slavery" under the provisions of section 2 of the thirteenth amendment. ${ }^{15}$

It is one purpose of the present comment to reassess the hundred years of ambiguous but omnipresent case law which led to the innovative decisions of the 1965 Term..$^{16}$ Contrary to the vehement dissent of the Court's critics, the view adopted in 1966 is not wholly without judicial antecedents. Furthermore, whatever is new in these decisions reflects considerations quite different from blatant constitutional reinterpretation. Fundamentally in issue is the whole question of the role of government in society, a role not rigidly prescribed by the Constitution itself nor imposed by the Warren Court. Having considered the reach of the recent decisions on the scope of the enforcement power, ${ }^{17}$ the comment will turn finally to a consideration of the limits on congressional authority to expand, contract, or modify civil rights standards. ${ }^{18}$

\footnotetext{
1383 U.S. 301 (1966).

"1384 U.S. 641 (1966).

'2U.S. ConST. amend. XIV, $§ 1$.

13383 U.S. 745 (1966).

"Although the opinion of the Court limited its decision to the reach of federal power to private persons acting in concert with federal officials, a majority of the Court stated explicitly that Congress may legislate to reach private actions where there is no state involvement at all. 383 U.S.at 761-62 (Clark, J., concurring, joined by Black \& Fortas, JJ.); 383 U.S. at 78184 (Brennan, J., partially dissenting, joined by Warren, C.J. \& Douglas, J.).

${ }^{15} 392$ U.S. at $439-44$.

"See notes 35-98 infra and accompanying text.

${ }^{17}$ See notes $99-172$ infra and accompanying text.

${ }^{18}$ See notes 173-208 infra and accompanying text.
} 


\section{THE ORIGINAL UNDERSTANDING}

A number of constitutional scholars have argued that the early judicial decisions which so confined the scope of congressional enforcement power were products of an erroneous beginning which have been perpetuated to the present time. The original error, it is suggested, could be corrected by a re-examination of the historical roots of the Civil War amendments and the interpretation given to them by their framers, members of the so-called Radical Republican Congress." ${ }^{19}$

Jacobus ten Broek in 1951 posed the question which was to occupy the Court's attention during the 1965 Term: whether the enforcement power of section 5 of the fourteenth amendment was intended to be corrective of positive state action only or was designed to revolutionize then current notions of federalism by conferring upon the national government the primary role of "directly and affirmatively" acting to protect individuals' section 1 rights. ${ }^{20}$ The answer was sought not only in the congressional debates of the period but also in the abolitionist antecedents which motivated many congressmen, ${ }^{21}$ for the abolitionists had been taught the advantage of access to national power formerly wielded by slave owners under the indulgence of Prigg v. Pennsylvania ${ }^{22}$ and Dred Scott..$^{23}$ The thirteenth amendment was envisioned as the instrument required to make this shift of national strength, cornbining as it did the philosophy of the Wilmot Proviso ${ }^{24}$ with an all-important grant of

\footnotetext{
"The present study will not attempt fully to develop the original understanding of the framers. Rather, the thesis propounded by ten Broek, Harris, Flack and others' is suggested in bold outline only for purposes of comparing the attitude of the Supreme Court's early decisions and its most recent pronouncements. A partial bibliography of the original understanding studies is collected in Frantz, Congressional Power to Enforce the Fourteenth Amendment Against Private Acts. 73 Yale L.J. 1353, n.4 (1964).

20. TEn Broek. The Antislavery Origins of the Fourteenth Amendment 2 (1951).

21 d. at 34.

z41 U.S. (16 Pet.) 536 (1842) (upholding constitutionality of the fugitive slave law under the Necessary and Proper Clause).

${ }^{2}$ Dred Scott v. Sanford, 60 U.S. (19 How.) 393 (1856). The Dred Scott decision by Chief Justice Taney declared unconstitutional, under the Due Process Clause of the fifth amendment, that section of the Missouri Compromise which prohibited slavery and involuntary servitude. Taney declared the act of Congress a deprivation of property, a Negro slave. merely because the owner himself entered or brought his property into a particular territory of the United States, and therefore without the due process of law.

${ }^{23}$ The "Wilmot Proviso" was an 1846 proposal of Congressman David Wilmot that "as an express and fundamental condition" to the acquisition by the United States from Mexico of new territory "neither slavery nor involuntary servitude shall ever exist in any part of said
} 


\section{congressional power. ${ }^{25}$}

The thirteenth amendment was thought by its framers to accomplish the whole of the abolitionists' ends, rather than the first step in a three-part process. ${ }^{26}$ Beyond the desires of the abolitionists to obtain the benefits of national power, however, there is little recorded reason to explain the exact content of the amendment's second section. ${ }^{27}$ Nevertheless, the authority to pass the Civil Rights Act of 1866 was deemed to arise under its provisions, a fact which suggests that the Act can appropriately be looked to for a contemporary congressional interpretation of the amendment. The debates surrounding the passage of the statute attest a concern over private as well as state violence under the Black Codes. ${ }^{28}$

The concern over private acts was partially matched by a competing interest in federalism espoused in the debates leading to the adoption of the fourteenth amendment. Yet it is clear that the amendment at least was designed to place the constitutionality of the

territory." The initial resolution was passed by the House but rejected by the Senate. The same proviso was proposed as an amendment to any relevant Congressional action for several years and produced an intense constitutional debate over the power of Congress to interfere with slavery in a territory which was the possession of all states, some free and some slave. The temporary solution to the controversy was a political one. the Compromise of 1850 , whereby California was admitted as a free state, and slavery was abolished in the District of Columbia. but the territories of New Mexico and Utah were created without the Wilmot Proviso and a stronger fugitive slave act was promulgated. E.g.. J. Hicks, THE FEDERAL UnION 486-500 (3d ed. 1957).

2 J. TEN BROEK, supra note 20, at 137-38.

2"The postulated steps are: (1) abolishment of slavery by the thirteenth amendment; (2) placement of the freed Negro in a position of civil equality through the fourtcenth; and (3) protection of his political rights by the fifteenth.. Id. See generally Gressman. The Unhappy. History of Civil Rights Legislation, 50 Mich. L. REv. 323, 325 (1952).

${ }^{27}$ Historical examination of the "common law" of slavery indicates, however, that mere removal of the institution of slavery would not effect a significant change in the status of the Negro, for Dred Scoll had found that the legal disabilities imposed on the slave were also borne by all freed persons of African descent. Thus, the second section was designed to "permit Congress to declare invalid those laws supportive of the slave system that were not rendered invalid by the first . . . " Kohl, supra note 1, at 274-76.

${ }^{2 x}$ The "Black Codes" were the enactments of the southern states during Reconstruction defining the civil rights of the ex-slaves and maintaining the Negro in a distinctly inferior position, Most, if not all, of the Codes denied to the Negro the right to vote, denied him the privilege of sitting on a jury, and of testifying when a white defendant was involved, required all labor contracts to be in writing to be enforceable, directed that Negro minors whose parents could not support them be apprenticed to a white master, and imposed excessive fines for vagrancy, which, if unpaid, might be collected by selling the services of the Negro. K.g. J. Hicks, supra note 24, at 624; J. TEN BROEK, supra note 20, at 163-64. However, there is substantial evidence that the Codes were not so harsh as generally supposed. See Kohl, supra note 1 , at $277-83$. 
1866 statute beyond doubt. ${ }^{29}$ Congressman Bingham's original proposal purported to give Congress full power in enforcing human rights. Subsequently, the form was changed from positive to negative in section 1 as a result of a compromise, partly explained by a fear for the maintenance of federalism but also responsive to the Radicals' demands that the states be bound by express provision and that the earlier Civil Rights Act concepts be embodied in constitutional doctrine, beyond the reach of congressional whim subject to change with a shifting majority. ${ }^{30}$

Although ten Broek and Harris point to the historical setting of the Radicals' three attempts to nationalize human rights protection, twice by amend ment and once by statute, and their efforts each time to correct the flaws to which the states' rights advocates clung, these scholars did not conclude that the Radicals were fully successful in giving the national government full and primary authority. ${ }^{31}$ Their view is more restrained, carrying the suggestion that a compromise was written into the fourteenth amendment which insured the national authority the power to act when state protection of civil liberties failed, as well as when state officials were the positive transgressors. ${ }^{32}$ This view is expressed in the most logical reading of the Equal Protcction Clause with particular emphasis upon the words "protection" and "deny." Thus, under section 1 a positive duty is demanded of the states to accord equal protection of the laws and due process, failure of which summons forth corrective measures by the national government under section 5.33

Another element in the ten Broek-Harris thesis which must be mentioned is the Republicans' grave mistrust of the judiciary as the governmental instrumentality primarily responsible for enforcing the national interests in human rights. Thus, the enforcement provisions of the Civil War amendments, as conceived by their framers, surely were intended to confer upon Congress the largest role in implementing national civil rights concerns. ${ }^{34}$

\footnotetext{
R. HARRIS, The QUeSt FOR EqualtTY 40 (1960).

20. TENBROEK, supra note 20, at 203; Gressman, supra note 26, at 1331-32.

${ }^{31}$ R. HARR1S, supra note 29, at 40-56; J. TENBROEK, supra note 20, at 204.

$2 \mathrm{~J}$. TEN BROEK, supra note 20, at 205-06, 224; R. HARRIS, supra note 29, at 42-43; see H. FLACK, THE ADOPTION OF THE FOURTEENTH AMENDMENT 55-97, 136-39 (1908).

${ }^{2}$ The three views on congressional power were evident in the debates over the Ku Klux Klan Act. 17 Stat. 13. where the Radicals claimed unlimited, primary, and exclusive power in Congress; the Democrat minority espoused the view of affirmative state action only; and the moderates thought in terms of state duty whether or not the breach involved state action or inaction. See R. HARR1S, supra note 29, at 45-52.

'H R. HARRIS, supra note 29, at 53-56.
} 


\section{The Supreme Court: Phase I}

It is a matter of great historical irony that a recalcitrant judiciary, so feared by the Radicals in Congress, in the long run should put the "state action" stamp on the fourteenth and fifteenth amendments and restrict notions of "badges of slavery" under the thirteenth to judicial definition..$^{35}$ Thus a large part of the whole field of civil rights discrimination was insulated from federal control; positive state aggression remained as only a minor exception. Moreover, the narrow area left to federal supervision was seemingly reserved to judicial rather than congressional surveillance. A more complete subversion of the intention of the Republican framers would be difficult to imagine. It is doubly ironic that the same institution which accomplished this remarkable feat should prove to be the only governmental body which in a later day would have the constitutional muscle, and perhaps the moral fortitude, to resurrect civil liberties to a position of national governmental concern. ${ }^{36}$

In spite of admirable efforts by figures like Harris, tenBroek, and Flack to establish the error of the earhest judicial decisions, most students of constitutional law resigned themselves to their wellfounded impression that the Civil Rights Cases $^{37}$ decision, its predecessors and progeny, did fashion an invincible theory of the Civil War amendments which restricted congressional authority from acting against all but consciously violative state action..$^{38}$ Despairing of any hope that these ancient precedents would be forthrightly overruled and holding few illusions that Congress would step in to fill the void even if overruling were obtained, modern day practitioners set about the task of stretching the concept of state action beyond recognition. ${ }^{39}$ This rather confined sphere of innovation proved to be fruitful for some purposes, but the need to point to some affirmative governmental involvement, however attenuated, set limits on the goal of uniform redress consistent with articulated national polices. ${ }^{40}$

\footnotetext{
${ }^{23}$ See notes 37-98 infra and accompanying text.

* See notes $99-172$ infra and accompanying text.

${ }^{37} 109$ U.S. 3 (1883).

${ }^{23}$ Consider even the view of Mr. Justice Douglas as of 1951: "The Fourteenth Amendment protects the individual against state action, not against wrongs done by individuals." United States v. Williams, 341 U.S. 70, 92 (1951) (dissenting opinion) (emphasis in the original).

"See, e.g., Evans v. Newton, 382 U.S. 296 (1966); Lombard v. Louisiana, 373 U.S. 267 (1963); Burton v. Wilmington Parking Authority, 365 U.S. 715 (1961); Shelley v. Kraemer, 334 U.S. 1 (1948); Marsh v. Alabama, 326 U.S. 501 (1946).

${ }^{\text {s0}}$ Consider the inability to obtain judicially required desegregation of public
} 
Laurent Frantz took a new tack which attempted to vindicate the ten Broek-Harris-Flack theory of original understanding without necessitating the overruling technique. ${ }^{11}$ His thesis that the early decisions were not incompatible with a "state inaction" concept, though perhaps demonstrable textually, stands against years of commonly accepted notions on the subject. A review of his findings coupled with a brief analysis of the early authority illustrates the fact that the current Supreme Court view on the extent of congressional enforcement power has proceeded much further afield from the relatively mild "state inaction" position than Frantz and the original intent explorers would have ever dreamed possible.

According to Frantz, the state action limitation grew out of a perversion of an originally sound idea: the framers recognized an implied power to protect against interference with a federally created right by private individuals, but an explicit command was needed to bind the states. ${ }^{12}$ Thus, the congressional power was made to extend even to state action. An alternative construct is in line with ten Broek's and Harris's more moderate view: The amendments create federal rights not only to freedom from state burdens but also to the benefit of certain state duties. Among these duties is that of affording due process and the protection of equal laws, the failure of which allows the national government to supply the relief withheld. Such substituted relief quite appropriately could act upon offending private individuals..$^{13}$

accommodations following the Civil Rights Cases, 109 U.S. 3 (1883), which compelled Congress to seek legislation under the Commerce Clause, Title 11 of the Civil Rights Act of 1964, 42 U.S.C. $\$ \S 2000 a-2000 a-6$ (1964).

"Frantz, supra note 19.

12 . at 1357.

"Frantz summarizes his thesis as follows:

1. The fourteenth amendment places the primary responsibility for enforcing equality of civil rights on the states but lodges in Congress adequate power to insure that the state's failure to discharge this responsibility shall not result in leaving these rights unprotected.

2. Where a racial group is discriminated against through a cultural pattern in which private acts play a part, the constitutional wrong, under the fourteenth amendment, is not the act of the individual, but the failure of the state to take adequate sters to prevent it, or to afford redress.

3. Congress, however, is not limited to striking directly at the constitutional wrong. It may also offset it by providing the protection which the state has failed to provide. But this power exists only when the state fails to do its duty.

4. Congress may provide in advance for a possible violation, but if it does so, such legislation must be made conditional on the state's failure to act.

5. Congressional legislation which impinges directly upon the conduct of private 
Frantz's view would have been most plausibly supported had the very earliest judicial utterances in the circuit courts been the last word. Three of these early expansive decisions were especially important to the future development of the state action concept in that the author of each subsequently was to write opinions for the Supreme Court which seemingly looked the other way, not to preserving the state inaction possiblity but to emphasizing the need for demonstrable state fault.

Judge W.B. Wood's position in United States $v$. Hall ${ }^{44}$ is at least different in tone and emphasis from his subsequent pronouncements in United States $v$. Harris. ${ }^{45}$ A pre-Slaughterhouse ${ }^{46}$ decision, the Hall opinion acknowledges the incorporation of the Bill of Rights into the Privileges and Immunities Clause of the fourteenth amendment and further recognizes broad congressional power to protect these rights:

From these ["equal protection" and "appropriate legislation"] provisions it follows clearly, as it seems to us, that congress had the power, by appropriate legislation, to protect the fundamental rights of citizens of the United States against unfriendly or insufficient state legislation, for the fourteenth amendment not only prohibits the making or enforcing of laws which shall abridge the privileges of the citizen, but prohibits the states from denying to all persons within its jurisdiction the equal protection of the laws. Denying includes inaction as well as aetion, and denying the equal protection of the laws includes the omission to protect, as well as the omission to pass laws for protection. The citizen of the United States is entitled to the enforcement of the laws for the protection of his fundamental rights, as well as the enactment of such laws. Therefore, to guard against the invasion of the citizen's fundamental rights, and to insure their adequate protection, as well against state legislation as state inaction, or incompetency, the amendment gives congress the power to enforce its provisions by appropriate legislation. And as it would be unseemly for congress to interfere directly with state enactments, and as it cannot compel the activity of state officials, the only

individuals and which operates uniformly regardless of the role plaved by the state is unconstitutional. But this is not because 'private acts' are beyond the limits of congressional power. Rather, it is because: (a) Congress may not presume that states will fail to discharge their constitutional duties; (b) Congress may not deprive the states. in advance of any default on their part, of the very function the amendment commands them to perform.

Id. at 1359. This analysis should be compared with the position that emerged from the decisions of the 1965 Term. See text accompanying notes 120-39 \& 157-72 infra.

"26 F. Cas. 79 (No. 15,282) (C.C.S.D. Ala. 1871).

${ }^{45} 106$ U.S. 629 (1883).

"Slaughterhouse Cases, 83 U.S. 36 (1873). 
appropriate legislation it can make is that which will operate directly on offenders and offenses, and protect the rights which the amendment secures. ${ }^{37}$

Apart from the confusing Privileges and Immunities reference, the quoted language is truly prophetic. in two respects: first in its express acknowledgment that congressional power can act upon the failure of a state to provide protection from discrimination, and second in its recognition that this power may act directly on individuals in their private capacities.

The soon-to-become Mr. Justice Strong echoed the Hall notion in United States $v$. Given :8 $^{48}$

It is, I think, an exploded heresy that the national government cannot reach all individuals in the states. It cannot invade the state domain. It cannot take cognizance of offences against state sovereignty. But when state laws have imposed duties upon persons, whether officers or not, the performance or non-performance of which affects rights under the federal government (as, for example, to vote, the right of citizenship, or the right to vote, so far as it is secured). I have no doubt that congress may make the non-performance of those duties an offence against the United States, and may punish it accordingly. This is not invading the state domain. It has no reference to violations of state laws. They remain punishable in the state courts."

Frantz does not distort the jurist's views when he remarks that Strong hardly took notice of the state action aspect of the case. ${ }^{50}$

One final circuit court decision deserves special comment. United States v. Cruikshan $k^{51}$ involved an indictment founded on sections 6 and 7 of the Enforcement Act of $1870 ; 52$ the opinion was delivered by $\mathrm{Mr}$. Justice Bradley, who was serving specially on the circuit bench to hear the case and who subsequently would author the Civil Rights Cases $^{53}$ decision. He had little difficulty in locating sufficient congressional power, both under the Necessary and Proper Clause as in Prigg ${ }^{54}$ and under the express enforcement sections, to enforce

\footnotetext{
$" 26$ F. Cas. at 81.

"25 F. Cas. 1324 (No. 15,210) (C.C.D. Del. 1873).

"Id. at 1328.

${ }^{50}$ Frantz, supra note 19, at 1365. The Given case involved an action under the Civil Rights Act of 1870 (Act of May 31, 1870, ch. 114, $\$ 2,16$ Stat. 140) against a state tax collector for his failure to give a Negro citizen an equal opportunity to perform certain prerequisites to qualify to vote. $25 \mathrm{~F}$. Cas. at 1324.

s1 25 F. Cas. 707 (No. 14,897) (C.C.D. La. 1874), affd on writ of error and cerfificate of division, 92 U.S. 542 (1875).

${ }^{52}$ Act of May 31, 1870. ch. 114, $\$ \$ 6-7.16$ Stat. 140.

${ }^{33} 109$ U.S. 3 (1883).

s Prigg v. Pennsylvania, 41 U.S. (16 Pet.) 539 (1842).
} 
the rights granted under the amendments. ${ }^{55} \mathrm{He}$ had more difficulty in defining those rights. In the case of the fourteenth and fifteenth amendments the federally protected right was access to state duties, and the federal remedy was available upon the failure of the state to perform its duty. ${ }^{56}$ Federal remedies may coexist with state remedies, and resort to federal machinery may take place upon a showing of an intent by the private individual to discriminate because of race plus, by implication, a failure of the state to protect the victim or to redress the wrong.

When the right of citizens of the United States to vote is denied or abridged by a state on account of their race, color, or previous condition of servitude, either by withholding the right itself or the remedies which are given to other citizens to enforce it, then, undoubtedly, congress has the power to pass laws to directly enforce the right and punish individuals for its violation, because that would be the only appropriate and efficient mode of enforcing the amendment. Congress cannot, with any propriety, or to any good purpose, pass laws forbidding the state legislature to deny or abridge the right, nor declaring void any state legislation adopted for that end. The prohibition is already in the constitutional amendment, and laws in violation of it are absolutely void by virtue of that prohibition. So far as relates to rendering null and void the obnoxious law, it is done already; but that does not help the person entitled to vote. By the supposition the state law gives him no remedy and no redress. It is clear, therefore, that the only practical way in which congress can enforce the amendment is by itself giving a remedy and giving redress. . . . There is no essential incongruity in the coexistence of concurrent laws, state and federal, for the punishment of the same unlawful acts as offenses both against the laws of the state and the laws of the United States. . . I am inclined to the opinion that congress has the power to secure that right not only as against the unfriendly operation of state laws, but against outrage, violence, and combinations on the part of individuals, irrespective of the state laws. ${ }^{57}$

Bradley concludes his analysis of the fifteenth amendment giving scant attention to the fourteenth by an important observation which seems firmly to plaee him into the "state inaction" camp:

Unless this distinction be made we are driven to one of two extremes-either that congress can never interfere where the state laws are unobjectionable, however remiss the state authorities may be in executing them, and however much a proscribed race may be oppressed; or that congress may pass an entire body of municipal law for the protection of person and property within the states, to operate concurrently with the state laws, for the protection and

\footnotetext{
${ }^{55} 25$ F. Cas. at 709-10.

${ }^{5}$ Id. at 710 .

sId. at 713 .
} 
benefit of a particular class of the community. This fundamental principle, 1 think, applies to both the 13th and 15th amendments..$^{53}$

More importantly, perhaps, are Bradley's observations as to the breadth of congressional power under the thirteenth amendment: Not only may Congress eradicate slavery but it may also bestow liberty as it attempted to do with the 1866 Civil Rights Act..$^{59}$ Enforcement machinery may be activated to deal with private discrimination based on race and unequal state treatment of either the aggressor or victim in the ordinary non-racially motivated crime because one of the parties is black. Bradley's position makes it abundantly clear that although state action or inaction is central to the second situation, that of unequal state treatment, federal power is plenary as regards private acts..$^{60}$

Given Bradley's disposition on circuit, his discernible shift in the Civil Rights Cases ${ }^{61}$ appears astounding. The solution to this puzzle is readily apparent when one notes the result of the espoused principles in the particular situation in Cruikshank: the indictment failed for absence of a specific allegation of intent based on race even though the facts of the case revealed a most heinous racial crime. ${ }^{82}$ Notably, Judge Woods dissented. ${ }^{63}$ Although compelled by the language of the Civil War amendments to reach certain results in the abstract, Bradley, and later his Supreme Court colleagues, still seemed ruled by the spirit of the Taney era in denying relief in concrete cases.

A possible explanation of the result in Cruikshank would be the obvious judicial requirement that a criminal indictment must be carefully drawn. The answer to such a contention would be the same as that to the application of the principle of narrow construction of criminal statutes to legislation penalizing an election official's misconduct: that the civil rights statutes and underlying remedies are as much remedial as penal, with the remedial aspect an authorization for broad construction. In United States v. Reese ${ }^{85}$ the

\footnotetext{
ss Id. at 714 .

"Id. at 711 .

${ }^{\infty}$ Id. at $711-12$.

"109 U.S. 3 (1883). See notes $85-98$ infra and accompanying text.

"The case arose from the "Colfax massacre" where supporters of the black Republican victors of a local election were trapped in a burning courthouse and shot to death as they sought to escape from a whitc mob. See H. Cummings \& C. McFarland, Federal Justice $241-42$ (1937). Frantz, supra note 19 , at 1365.

c25 F. Cas. at 708 (no opinion).

c92 U.S. 214 (1875).
} 
court struggled to read certain sections of the Enforcement $\mathrm{Act}^{65}$ as not explicitly restricted to racially discriminatory refusals to receive votes. The statute thus interpreted suffered from constitutionally impermissible overbreadth, in spite of the fact that the discrimination charged could have been reached by a properly drafted statute. ${ }^{66}$ The disposition to regard civil rights legislation as penal rather than remedial had large and lasting effects on constitutional adjudication until the Reese case was expressly rejected in $1960 .{ }^{67}$

The restrictive approach to statutory construction, which was new with the Reese decision, was soon to be supplemented by an enormously expanded concept of judicial review. Following a series of decisions authored by Mr. Justice Strong during the 1880 Term, one might have thought that the question of scope of review had been firmly settled in favor of a strict limit on judicial supervision. In $E x$ parte Virginia, ${ }^{68}$ which involved an indictment of a state judge for racially motivated jury exclusion, Strong urged:

It is not said the judicial power of the general government shall extend to enforcing the prohibitions and to protecting the rights and immunities guaranteed. It is not said that branch of the government shall be authorized to declare void any action of a State in violation of the prohibitions. It is the power of Congress which has been enlarged. Congress is authorized to enforce the prohibitions by appropriate legislation. Some legislation is contemplated to make the amendments fully effective. Whatever legislation is appropriate, that is, adapted to carry out the objects the amendments have in view, whatever tends to enforce submission to the prohibitions they contain, and to secure to all persons the enjoyment of perfect equality of civil rights and the equal protection of the laws against State denial or invasion, if not prohibited, is brought within the domain of congressional power."

\footnotetext{
"Act of May 31, 1870, ch. 114, $\$ \$ 1-4,16$ Stat. 140. The organization of the Enforcement Act is quite logical, the first section confirming the right to vote without discrimination on account of race and the second, third, and fourth sections creating penalties for refusing to provide an equal opportunity to perform any prerequisites to qualify to vote, for refusing to receive such a vote, or for obstructing a person in the exercise of the right to vote. Reese involved an election official's racially motivated refusal to recieve a vote under section three. The official argued, asserting jus lertii, that section three did not directly refer to racial refusals in spite of the context of the section in the statute as a whole and in disregard of language which seemed to incorporate section one by "aforesaid" reference. 92 U.S. at 21820.

"See 92 U.S. at 241 (dissenting opinion).

or United States v. Raines, 362 U.S. 17, 24 (1960). See notes 106-16 infra and accompanying text.

" 100 U.S. 339 (1879).

"Id. at 345-46.
} 
Similarly, Strauder $v$. West Virginia ${ }^{70}$ confirmed the congressional power to determine the particular form and manner of protection, there the federal court removal statute, which would be adopted to insure fourteenth amendment rights. The removal statute did come under closer scrutiny in Virginia v. Rives ${ }^{71}$ where protection under the particular facts was required to be accorded instead through the revisory powers of the Supreme Court, ${ }^{72}$ but the Rives decision in no way is to be deemed inconsistent with its companion cases which announced a broad congressional power with limited judicial review.

Over the objection of Mr. Justice Harlan that the McCulloch standard was being abandoned, ${ }^{73}$ in spite of the fact that the framers of the Civil War amendments greatly feared the heavy hand of judicial power and acted expressly to enhance congressional power by these amendments, ${ }^{74}$ and in direct contradiction to his previous position on the thirteenth amendment, ${ }^{75} \mathrm{Mr}$. Justice Bradley in the Civil Rights Cases $^{76}$ ignored the ponderous presumption of constitutionality of an act of Congress and substituted the Supreme Court as final arbiter of what conduct constitutes the imposition of a badge of slavery. ${ }^{77}$ Even without more, the combination of restrictive statutory construction and jealously exercised judicial review tantamount to a substituted judgment distinctly identifies a poorly masked judicial hostility brought to bear on civil rights legislation. ${ }^{78}$

Following the Reese standard of narrow statutory construction and the Civil Rights Cases expansion of judicial review, the little vitality that remained to congressional power under the Civil War

\footnotetext{
7100 U.S. 303 (1879).

"100 U.S. 313 (1879).

"The Court adopted the view that where a judge systematically excludes Negroes from jury service contrary to state law, he acts in his private capacity, and it must be presumed that the state will redress the discrimination. $\dot{I} \dot{d}$. at 334 .

${ }^{73}$ Civil Rights Cases, 109 U.S. 3, 51 (1883) (dissenting opinion). The "McCulloch standard" by which congressional power to cnforce the Civil War amendments is to be measured is John Marshall's pronouncement in McCulloch v. Maryland, 17 U.S. (4 Wheat.) 316 (1819), that acts of Congress must be deemed constitutional if appropriate and unprohibited means of achieving a legitimate end. Id.

"See note 34 supra and accompanying text.

${ }^{75}$ United States v. Cruikshank, 25 F. Cas. 707, 711 (No. 14,897) (C.C.D. La. 1874), affd on writ of error and certificate of division, 92 U.S. 542 (1875).

$" 109$ U.S. 3 (1883).

"Id. at 20-22.

${ }^{73}$ Compare McCulloch v. Maryland, 17 U.S. (4 Wheat.) 316.430 (1819) (taxing power).
} 
amendments and accompanying legislation was all but fully emasculated by the adoption of the "state action only" theory of constitutional interpretation. The Cruikshank case reached a hearing in the Supreme Court in 1875, where Chief Justice Waite took over the responsibilities as decision writer from Mr. Justice Bradley who had authored the circuit court opinion. ${ }^{79}$ The quashing of the indictment was affirmed in the high court, ${ }^{80}$ but the tenor of the decision lay stress not upon an openness to the state inaction concept, which Bradley indulged in below, ${ }^{81}$ but upon the importance of notions of federalism which placed primary responsibility upon the states in the protection of civil rights. ${ }^{82}$

Next to be lost to the ranks of civil rights opponents was $\mathrm{Mr}$. Justice Woods, author of the enlightened Hall decision, who found insufficient an indictment under the $\mathrm{Ku}$ Klux Klan $\mathrm{Act}^{83}$ of private individuals for the lynching of several Negroes who were being held in the custody of a deputy sheriff. The Harris ${ }^{84}$ decision held the statute overbroad since it applied regardless of how well the state might have performed its duties. Despite adherence to the inaction concept, Woods nonetheless was greatly influenced by the Reese gloss on statutory construction as well as by the Cruikshank-Rives presumption of state fulfillment of its equal protection duty.

"See note 53 supra and accompanying text.

wUnited States v. Cruikshank, 92 U.S. 542 (1875).

"See notes 56-58 supra and accompanying text.

"Compare Frantz, supra note 19, at 1370-73. The author finds redeeming value in the Chief Justice's decision only in that it did not expressly reject the more liberal reading by Mr. Justice Bradley on Circuit.

The Cruikshank decision adopted the Slaughterhouse distinction between state and national citizenship, whereby the "fundamental rights" embodied in the Declaration of Independence and Constitution were deemed privileges and immunities not of national but of state citizenship. National citizenship entitled one only to the right to travel to the national capital to petition the federal government, access to federal courts, protection when traveling abroad and other rights involving no state contact. Thus, the Court found that the indictment failed to allege that the right claimed to have been violated, the right to assemble, was one arising from the Negro's relationship to the fedcral government-that the assembly was for the purpose of dealing with some function of the federal government.

This narrow construction of the incidents of national citizenship is thought to be contrary to the intent of the framers and made possible only by imprecise drafting of the amendment and disregard of the legislative history. E.g.. Gressman, supra note 26, at 1332-39. But $\mathrm{c}$. F. Strong. American Constitutional Law 135 (1950): The real import of the Slaughterhouse-Cruikshank rationale "lies in its profound contribution to the preservation of a federal system threatened by derangement as a consequence of victorious Nationalism." Id.

Act of April 20, 1871, ch. 22, $\$ \$ 1-7,17$ Stat. 13.

sUnited States v. Harris, 106 U.S. 629 (1882). 
Virtually all of the foregoing judicial techniques, which contributed to the eventual demise of the lofty aims of the Radical Republican framers, find their ultimate expression in the now famous Civil Rights Cases. ${ }^{85}$ A careful analysis of the opinion is a tedious process, because it is contradictory and conceptually overlapping at every turn. The cases rested on the first two sections of the Civil Rights Act of $1875,{ }^{86}$ which provided for equal enjoyment of public accommodations regardless of race, enforceable against private interference. Mr. Justice Bradley gave separate attention to the constitutionality of the Act under the fourteenth amendment and under the thirteenth. The constitutional failure of the statute under the fourteenth amendment was deemed to be its application ex directo against private persons with no reference to any offending state action. ${ }^{87}$ Even in Bradley's opinion the phrase "state action" is assertedly not incompatible with inaction or passive refusal to supply a remedy, ${ }^{88}$ and perhaps this is so. However, nearly every direct reference to state duty by Bradley is couched in terms of some positive activity. Congressional power is limited to rendering state acts "null, void, and innocuous." only affirmative acts may be voided, some additional language would have been used to allow substituted performance of the state duty were inactivity a villain." "If the laws themselves make any unjust discrimination, amenable to the prohibitions of the Fourteenth Amendment, Congress has full power to afford a remedy under that amendment and in accordance with it." ${ }^{91}$ The possibility that inaction is here a constitutional evil is rather fleeting in light of the fact that the Court virtually elevates to a position of judicial

$\$ 109$ U.S. 3 (1883). The make-up of the Court had changed a few years later when Mr. Justice Bradley announced the decision in the Civil Rights Cases: Woods, Matthews, Gray, and Blatchford were replaced by Clifford, Strong, Hunt, and Swayne.

${ }^{*}$ Act of March 1, 1875, ch. 114, \$\$ 1-4, 18 Stat. 335.

$\pi 109$ U.S. at 14.

"Frantz, supra note 19, at 1380.

109 U.S. at 11.

"The state action concept is pointedly analogized to the prohibition against statc laws impairing the obligation of contracts. Id. at 12. It stretches credulity to suggest that Bradley would have accepted the notion that ordinary private interference with contractual relations could be elevated to constitutional dimensions by virtue of the Impairment of Contracts Clause. Nor would such a result be reached under the rationale of Guest. See notes 162-72 infra and accompanying text. The analogy does express an orientation of the opinion, however, or else it must be written off as another mark of the confused reasoning evident throughout.

" 109 U.S. at 25 (emphasis added). 
notice $^{92}$ the Rives presumption that state laws and procedures are ever ready to remedy civil wrongs irrespective of race.

Bradley's approach to the thirteenth amendment in Cruikshank has already been noted..$^{93}$ In the Civil Rights Cases opinion he again conceded that congressional power could be brought to bear on individuals, irrespective of state involvement, in a direct and primary manner for the purposes of eradicating badges of slavery. ${ }^{94}$ However, the Court, in a substitution of judgment carefully disguised as judicial review, ${ }^{95}$ held that racial discrimination itself is not to be viewed as a badge of slavery even though such discrimination is forbidden to the states by the fourteenth amendment. If, as Frantz suggests, such discrimination is not only forbidden to the states, but the protection of persons from private discrimination is required of the states as a positive duty, then what sort of national legislation can insure that this duty will be fulfilled? Judge Woods supplied the only answer when he delivered the Hall opinion: legislation operative directly against private offenders. ${ }^{96}$ Twelve years later, Woods merely acquiesced in Bradley's unsubstantiated assumption of state redress. ${ }^{97}$

Frantz, writing rather prophetically in 1964, seemed unwilling to recognize the possibility that the Civil Rights Cases standard of congressional power was ever likely to be abandoned. The cases could be re-examined to demonstrate the continuing vitality of the state inaction concept. Once these decisions are stripped of the now acknowledgedly antiquated notions of strictly limited statutory construction, broad judicial discretion in scope of review, and automatic assumption of state redress in the face of compelling contrary evidence, the Frantz thesis has merit: the little that remains

\footnotetext{
n"Can the act of a mere individual . . . be justly regarded as imposing any badge of slavery ... or only as inflicting an ordinary civil injury, properly cognizable by the laws of the State. and presumably subject to redress by those laws until the contrary appears?" Id. at 24 (emphasis added). The confusion of thirteenth amendment terminology with fourteenth amendment ideas of state action is not explained.

See notes 59-60 supra and accompanying text.

109 U.S. at 20, 23.

"5Id. at 10. "We have carefully considered those arguments, as was due to the eminent ability of those who put them forward, and have felt, in all its force, the weight of authority which always invests a law that Congress deems itself competent to pass. But the responsibility of an independent judgment is now thrown upon this court; and we are bound to exercise it according to the best lights we have." Id.

"See text accompanying note 47 supra.

"See note 92 supra.
} 
in the domain of actual constitutional interpretation reveals a flexible concept of state duty. What the Frantz analysis unconsciously hides from view is the radical shift in judicial attitudes in the twelve years between Hall and Civil Rights Cases, a shift which arguably is explainable as a gradual judicial dismantling of the Reconstruction experiment which developed concurrently with congressional and public acquiescence, as the abolitionist sentiment associated with the Radical Republicans began to dissipate..$^{98}$ The decisions of the 1965 Supreme Court Term, although reflecting other forces, surely portended a return not to the essential moderation of the early civil rights opinions, even as reconstructed by Frantz, but to the more radical commitment of the national power for the protection of civil rights exhibited by the framers of the Civil War amendments and the accompanying legislation.

\section{The Supreme Court: Phase 11}

The civil rights movement, so far as the aid of the national government was concerned, made little progress from 1883 until 1954. Some civil rights decisions were handed down by the high court during this period, but all should agree that the spirit of activism now synonymous with the Warren Court dates from Brown v. Board of Education." The history of the seventy-year lull in civil rights activity need not be retold: the dislocation of reconstruction by the judicial branch corresponded nicely with the fading of congressional sympathy for such reform. The relatively small area within which the Civil War amendments could function was strictly relegated to judicial supervision. Liberal, but short range, judicial innovation took the form of stretching and molding the concept of "state action" to fit an infinite variety of situations. ${ }^{100}$ Congressional involvement was forgotten, and Congress liked it that way.

Brown v. Board is a landmark decision in the present regard because it identifies the beginning of a new judicial attitude toward the rejuvenated civil rights movement which may be characterized as requiring affirmative obligations on the part of government. Archibald Cox has argued that the image of the Warren Court as

"The Dred Scort sentiment which still lived in the majority's opinion was duly noted by Mr. Justice Harlan in his dissenting opinion. 109 U.S. at 57.

" 347 U.S. 483 (1954).

ton Cases cited note 39 supra. 
requiring and encouraging a positive involvement of government in the whole enterprise of protecting human rights is its most significant achievement over the past 15 years. ${ }^{101}$ The role of the Court during these years has had several consequences. First, its activism did not go unnoticed by the other branches of government. Arising from nearly a century of inactivity, Congress moved slowly to keep pace with the politics of the times by adopting its first civil rights statute since 1875, the Civil Rights Act of 1957,102 and the Executive branch responded. ${ }^{103} \mathrm{~A}$ second consequence springs from the active role which the Court was fashioning for the national government. The one clear note sounding through the criticism of the Court was that the role of activist did not suit the judiciary, an essentially passive institution. The Court's failures in the school desegregation time table ${ }^{104}$ and in voter registration ${ }^{105}$ are illustrative of what was essentially an institutional handicap. The movement needed powerful and flexible remedies and preventive action coupled with equally powerful enforcement machinery. Having contributed political muscle to the civil rights movement, the Court's momentum shifted to a new focus. Once again Congress was prepared to act, and the Court's new role was to undergird the exercise of congressional power with constitutional authority.

In meeting this new challenge the Court was faced with several weighty legacies from its less sympathetic predecessors of the Reconstruction era. The first problem was the barrier most often noted by the authorities: the state action concept of constitutional interpretation which barred direct congressional attack on the evils of private discrimination. The second problem, discussed extensively

\footnotetext{
"A. Cox. The Warren Court (1968).

im71 Stat. 634 (codified in scattered sections of 5, 28, 42 U.S.C. (1964)).

1ra Although the Act gave the Attorney General the power to institute civil actions to protect persons against deprivations proscribed by the Act, the legislation had little practical effect, largely because the Justice Department had difficulty both in obtaining favorable decisions in southern district courts and in securing data on voter registration. Moreover, only three suits were filed by the Justice Department during the first two years after enaetment. See. e.g.. Kommers, The Right to Vote and its lmplementation, 39 Notre Dame Law. 365, 378-84 (1964).

in' In Alexander y. Holmes County Bd. of Educ., 90 S. Ct. 29 (1969) (per curiam), the Court repudiated its former standard of "with all deliberate speed" and replaced it with "at once." Thus, 15 years after Brown v. Board of Educ. 347 U.S. 483 (1954), much remained to be done.

ins See South Carolina v. Katzenbach, 383 U.S. 301, 310-15 (1966); Note, Voting Rights Act of 1965. 1966 DuKe L.J. 463, 467-68. See note 205 infra and accompanying text.
} 
above, was the inhibiting influence on congressional action of the numerous judicial techniques, chiefly construction and review, employed by the Court during Reconstruction to limit legislative innovation. It is a central thesis of the present comment that the second cluster of problems posed a far graver problem to the future of the protection of human rights than did the state action limitation, and that these "lower level" constitutional concerns were well on their way to being differently viewed even before 1954 . Finally, it should also become clear that any alterations in the present understanding of state action that have indeed taken place have been the product not of "whole cloth" innovation by the Court but by changes in fundamental notions of government's role in society.

\section{Judicial Techniques: Statutory Construction}

United States v. Reese, as demonstrated earlier, was a crucial decision in placing stringent controls upon congressional reform by requiring Congress to walk the tightrope of strict statutory construction in order for its acts to pass judicial muster. ${ }^{108}$ Indeed, the judicial attitude that civil rights statutes are essentially penal and, thus, to be narrowly construed, remained a fixed notion of the Court until very late in the day. It was not until 1960 that the Court rejected the availability of a jus tertii attack for overbreadth of a civil rights statute. ${ }^{107}$ The overbreadth problem, however, reflected the judicial tendency to be somewhat unsympathetic to civil rights legislation. That this general hostility did shift in recent years and that the remedial character of these statutes became the central object of consideration is perhaps best illustrated by the 1965 Term decision United States $v$. Price, ${ }^{108}$ which concerned the propriety of indictments against the participants in the murders of civil rights workers in Philadelphia, Mississippi. The district court had sustained an indictment against several police officers charging a conspiracy to violate section 242 of the criminal code ${ }^{109}$ but had

\footnotetext{
i"See. e.g.. James v. Bowman, 190 U.S. 127 (1903). See notes $64-67$ supra and accompanying text.

in United States v. Raines. 362 U.S. 17 (1960).

$1 \mathrm{~m} 383$ U.S. 787 (1966).

10 "Whoever, under color of any law . . . wilfully subjects any [person] to the deprivation of any rights . . . secured or protected by the Constitution or laws of the United States, or to different punishments, pains, or penalties ... by reason of his color, or race, than are
} 
dismissed the substantive charge of a section 242 violation as to the non-official alleged participants. Delivering the unanimous opinion, Mr. Justice Fortas warned at the outset that the "sole question" was one of construction and not constitutional power, ${ }^{110}$ and he gave a broad construction to the "under color of law" provision of the statute, holding that it would apply to private persons acting in concert with state officials. Secondly, the Court reinstated the felony charge under section 241 , which punishes a conspiracy to injure the enjoyment of any right secured by the Constitution. ${ }^{111}$ The Court's decision that section 241 includes within its penumbra rights secured by the fourteenth amendment laid to rest a controversy which had existed since the Court split on the question 15 years earlier. ${ }^{112}$ The language in Price is now typical of current indulgence of civil rights statutes: "We think that history leaves no doubt that, if we are to give section 241 the scope that its origins dictate, we must accord it a sweep as broad as its language."113

The most recent illustration of the Warren Court's reaction to strict statutory construction is Jones v. Alfred H. Mayer Co., ${ }^{114}$ which allows remedies for housing discrimination arguably far in excess of the intent even of the Radical Republican. framers of the 1866 statute there involved.115 Quoting the above language from Price, the Court concluded after a review of the legislative history

prescribed for the punishment of citizens, shall be [guilty of a misdemeanor]." 18 U.S.C. $\S 242$ (1964).

i"183 U.S. at 789.

II" "If two or more persons conspire to injure, oppress, threaten, or intimidate any citizen in the free exercise or enjoyment of any right or privilege secured to him by the Constitution or laws of the United States, or because of his having exercised the same; or

If two or more persons go in disguise on the highway, or on the premises of another, with intent to prevent or hinder his free exercise or enjoyment of any right or privilege so secured-

They shall be [guilty of a felony]." 18 U.S.C. $\$ 241$ (1964).

"IzUnited States v. Williams, 341 U.S. 70 (1951).

"1'383 U.S. at 801 . The Court drew heavily from the context of events at the time of the framing of the statutes in 1866 and 1870 . Id. at 803-05.

"'392 U.S. 409 (1968).

"SAct of April 9, 1866, ch. 31, § 1, 14 Stat. 27, reenacted by Act of May 31, 1870, ch. $114, \$ 18,16$ Stat. 140 . In pertinent part, the statute reads:

[C]itizens, of every race and color . . . shall have the same right, in every State and Territory in the United States, to make and enforce contracts . . . [and] to inherit, purchase, lease, sell, hold, and convey real and personal property . . . as is enjoyed by white citizens ... . any law, statute, ordinance, regulation, or custom, to the contrary notwithstanding. Id.

These provisions are presently codified in substantial part in 42 U.S.C. $\S \S 1981-82$ (1964). For discussion of the Court's decision, see commentary cited note 1 supra. 
that the first civil rights act, in granting all people, on an equal plane with white citizens, the right to make and enforce contracts and to purchase and sell property, was intended to be enforceable against solely private discrimination on the basis of race in the sale of housing. ${ }^{116}$ Even if the express holding in Reese was overruled by United States $v$. Raines, ${ }^{117}$ the spirit of strict statutory construction left by Reese was finally expunged by the remedial attitude which influenced Price and Alfred Mayer. Thus, the first bastion of the anti-reconstruction judiciary of old had evaporated as a technique to defeat reform.

\section{Judicial Techniques: Scope of Review}

An even more formidable inhibition on the exercise of congressional power, as the Civil Rights Cases decision so vividly attests, is the unsparing exercise of judicial review over statutory enactments. ${ }^{118}$ It should be clear from the earlier discussion that countervailing forces arose with the first civil rights decisions: at the opposite pole from Bradley's position was the view taken by Mr. Justice Strong in Ex parte Virginia. ${ }^{119}$ The fact that the Civil Rights Cases ultimately carried the day did not dissuade Chief Justice Warren from returning to the insight of the earlier case in announcing the result in South Carolina v. Katzenbach. ${ }^{120}$ Congress had acted in the face of the paucity of judicially created remedies to protect against voting discrimination by providing in the Voting Rights Act of $1965^{121}$ new remedies aimed at geographical areas of hard core discrimination and designed to catch racial discrimination in its incipiency. ${ }^{122}$ The Attorney General had certified the need for

II'392 U.S. at 422-36.

${ }^{117} 362$ U.S. 17 (1960). See notes 64-67 supra and accompanying text.

"See notes 73-78 supra and accompanying text.

"'100 U.S. 339 (1879). See text accompanying note 68 supra.

126383 U.S. 301 (1966). Archibald Cox was among the first to recognize the enormous importance of the 1965 Term decisions for their expansion of congressional power. Cox, supra note 9. The main emphasis of the article deals with an understanding of these decisions in light of a larger appreciation of the Warren Court's emphasis on affirmative obligations on the part of government in protecting human rights. See notes $135-61$ infra and accompanying text.

12142 U.S.C. \$ 1973 (Supp. 111, 1968).

${ }^{122}$ Remedies included suspension of literacy tests where historically substantial discrimination had occurred, review of proposed new voting regulations in advance of the effective date, and the appointment of federal registrars. 42 U.S.C. $\$ \$ 1973 \mathrm{a}-1973$ p (Supp. 111. 1968). The design of the statute was to allow federal intervention when state records of voting indicated the probability of discrimination according to a rather mechanical test. See. 
federal registrars in South Carolina and ordered the suspension of literacy tests. South Carolina brought an original action in the Supreme Court urging that certain sections of the statute were in excess of congressional power and violative of the tenth amendment. The Court, however, refused the invitation to second-guess the propriety of the enactment under the auspices of judicial review but instead located ample authority for the legislature's exercise of power under the enforcement section of the fifteenth amendment: "As against the reserved powers of the States, Congress may use any rational means to effectuate the constitutional prohibition of racial discrimination in voting." 123 The Chief Justice observed that the amendment is self-executing under section 1 , but Congress may implement its provisions under section 2 , pointing to the ancient truth that the amendment was originally understood chiefly in terms of enlarging congressional power. ${ }^{124}$ The Civil Rights Cases were unmentioned in the course of the Court's opinion, but it is abundantly clear that the real victor was the elder Mr. Justice Harlan, who eighty years earlier had been rebuked for attempting to draw upon the McCulloch standard as the test for judicial review. ${ }^{125}$

Having re-established a restrained approach to judicial review, it was but a short step in the Court's analysis to mark the appropriateness of the congressionally founded remedies to the particular evils at hand. Three features of the Court's analysis deserve special attention. First, the Chief Justice countered South Carolina's argument that sanctions were imposed only on a few of

c.g.. 1966 DUKE L.J., supra note 105. Timely enforcement under earlier statutes had proven impossible. See 383 U.S. at 310-14.

12383 U.S. at 324.

${ }^{124}$ [T] he Framers indicated that Congress was to be chiefly responsible for implementing the rights created in $\S 1$. "It is the power of Congress which has been enlarged. Congress is authorized to enforce the prohibitions by appropriate legislation. Some legislation is contemplated to make the [Civil War] amendments fully effective." $E x$ parte Virginia, 100 U.S. 339, 345 [1879]. Accordingly, in addition to the courts. Congress has full remedial powers to effectuate the constitutional prohibition against racial discrimination in voting. 383 U.S. at 326 .

Mr. Justice Black concurred in this aspect of the Court's opinion but gave congressional power an even broader sweep: "I do not base my conclusion on the fact that the formula is rational, for it is enough for me that Congress by creating this formula has merely exercised its hitherto unquestioned and undisputed power to decide when, where, and upon what conditions its laws shall go into effect." Id. at 356 (Black, J.. concurring and dissenting).

${ }^{123}$ Civil Rights Cases, 109 U.S. 3, 51 (1883) (Harlan, J., dissenting). Compare 383 U.S. at 326-27. 
the discriminating states, by observing that Congress is allowed to approach the problem a step at a time and that the underinclusiveness of the classification is not adequate grounds for reversing congressional judgment. ${ }^{126}$ Second, the Court refused to rule that Lassiter v. Northampton County Board of Elections, ${ }^{127}$ in which the Court upheld the constitutionality of literacy tests per se. precluded Congress from reaching a different judgment in specific situations. ${ }^{128}$ Finally, the majority approved the technique whereby a state which suffered charges by the Attorney General must receive advance approval from the Justice Department for any changes in the state's voting regulations. ${ }^{129} \mathrm{Mr}$. Justice Black's vehement dissent, arguing that such advance approval violates notions of federalism, dramatically called attention to an enhanced congressional authority to employ preventive as well as corrective measures. ${ }^{\text {i30 }}$

The major tenets of South Carolina are echoed and expanded in Katzenbach v. Morgan, ${ }^{131}$ a later decision of the same term. The controversy centered upon the conflict between section 4(e) of the 1965 Act, ${ }^{132}$ which suspended literacy tests as a condition upon the right to vote for those citizens who were educated in an "american flag school" where the predominant classroom language was other than English, and a New York rule ${ }^{133}$ which imposed such tests on, among others, its Puerto Rican community. The Supreme Court reversed a judgment which, on tenth amendment grounds, enjoined the application of section 4(e), finding the statute appropriate under section 5 of the fourteenth amendment as an enforcement of the Equal Protection Clause in section 1. As in South Carolina, the Court observed that the fourteenth a mendment was intended primarily to augment congressional rather than judicial power, and held the Lassiter decision inapposite, finding that Congress must be unfettered by any requirement that the judiciary pass in advance

122383 U.S. at 331 .

12360 U.S. 45 (1959).

122383 U.S. at 333-34. This position provided the entering wedge in Katzenbach v. Morgan. 384 U.S. 641 (1966), for future congressional expansion of civil rights standards beyond those which the courts acting alone could require. See text accompanying note 134 infra.

12383 U.S. at 334-35.

120/d. at 358-62 (Black, J., concurring and dissenting).

131384 U.S. 641 (1966).

1242 U.S.C. \& 1973b(e) (Supp. IV, 1969).

12N.Y. CONST. art. 2, § I. See 384 U.S. at 644 n.2. 
upon the constitutionality of the substantive conduct sought to be proscribed. The question becomes not what the judicial branch will find but whether section 4(e) is "appropriate legislation" under section 5 of the fourteenth amendment. ${ }^{134}$ The test of "appropriateness," of course, is the McCulloch standard analogized from the Necessary and Proper Clause. Arguably, Mr. Justice Brennan goes even further in Morgan than the Chief Justice was required to go in South Carolina: In the conflict between state and federal interests, words like "reasonable relation" and "rational" play no part in the judicial determination. ${ }^{135}$ Rather, "[i]t is enou gh that we be able to perceive a basis upon which the Congress might resolve the conflict as it did."136 This loose standard, or nonstandard, operates in an especially dramatic way in Morgan in light of the absence of any compelling legislative history to suggest that Congress did indulge an actual balancing of competing interests. That the Congress might have done so was sufficient for the majority's "perceive a basis" test. ${ }^{137}$

For purposes of the scope of review, the central issue which divided the Court in Morgan is interrelated with the discussion of the extent of congressional enforcement power but is an issue which might be overlooked but for the dissenting opinion which forces it upon the attention of the majority. It is one thing, said the dissenters, broadly to construe enforcement power; it is another to say when that power is authorized to take effect. ${ }^{138}$ The majority's insistence that Congress may determine "when and where" its authority is to be exercised is the first clear break with the older decisions which refused to relinquish the final authority to determine whether the exercise of power was designed to reach judicially acknowledged evils. The dissent is surely correct in its observation that Morgan grants not only a large area within which Congress might legislate, but also confers upon Congress the power to draw the boundaries themselves by its ability "to define the substantive scope of the Amendment."139

'3384 U.S. at 649-50.

${ }^{125}$ See Cox, supra note 9, at 104.

12384 U.S. at 653.

${ }^{137 / d}$. The absence of legislative history troubled the dissenters. Id. at 669 (dissenting opinion).

$19 x / d$. at 666 (dissenting opinion).

${ }^{139} / d$. at 668 (dissenting opinion). The dissenters' observation also raised an important 
After the Morgan decision, Jones $v$. Alfred H. Mayer Co. ${ }^{140}$ may seem to be little more than frosting on the cake. The case does deserve comment, however, for several reasons. First, it is a testimonial that the Supreme Court's position on scope of review was not just an eccentric pronouncement of the 1965 Term. Second, and more importantly, the decision completes the full coverage by the Court of the Civil War amendments, applying the McCulloch standard to the thirteenth amendment:

If Congress has power under the Thirteenth Amendment to eradicate conditions that prevent Negroes from buying and renting property because of their race or color, then no federal statute calculated to achieve that objective can be thought to exceed the constitutional power of Congress simply because it reaches beyond state action to regulate the conduct of private individuals.

"By its own unaided force and effect," the Thirteenth Amendment "abolished slavery, and established universal freedom." . . . Whether or not the Amendment itself did any more than that-a question not involved in this case-it is at least clear that the Enabling Clause of that Amendment empowered Congress to do much more. For that clause clothed "Congress with power to pass all laws necessary and proper for abolishing all badges and incidents of slavery in the United States."

....

"It was for that purpose that the second clause of that amendment was adopted, which says that Congress shall have authority, by appropriate legislation, to carry into effect the article prohibiting slavery. Who is to decide what that appropriate legislation is to be? The Congress of the United States; and it is for Congress to adopt such appropriate legislation as it may think proper, so that it be a means to accomplish the end."'H!

The most significant-feature in this regard of Alfred Mayer, however, is that it directly contradicts the approach of the Civil Rights Cases in its analysis of congressional power under the thirteenth amendment. ${ }^{142}$ After Alfred Mayer there is little reason to

question of whether congressional power of definition can also be used to "dilute" equal protection standards. See notes $190-97$ infra and accompanying text.

1"392 U.S. 409 (1968).

is' Id. at 438-40 (citation omitted).

${ }^{132}$ Compare notes $73-78$ supra and accompanying text. The majority bypassed the reconsideration of the Civil Rights Cascs by observing that the question as presented on the public accommodations issue is "largely academic" since the enactment of Title 11 of the Civil Rights Act of 1964. Id. at 441 n.78. However, the Hodges decision which the Court did overrule is indistinguishable from the Civil Rights Cases on the central question of who may decide what constitutes a "badge of slavery" for thirteenth amendment, $\S 2$, purposes, even though the result in the Civii Rights Cases might be regarded a less illiberal judicial determination than that in Hodges. 
suppose that the public accommodations statute declared unconstitutional in 1883 would not pass judicial muster today regardless of state action considerations, or that a fully adequate constitutional basis for the Civil Rights Act of $1964,1^{143}$ at least so far as race is concerned, could not be articulated absent any reliance upon the Commerce Clause. ${ }^{14}$

\section{Constitutional Interpretation}

Following the several decisions which changed the direction of judicial treatment of statutory construction and judicial review, what is left of the precedential force of the Civil Rights Cases? Although the Civil Rights Act of 1875 might be treated differently under the Alfred Mayer understanding of the thirteenth amendment, the scope of review considerations, without more, do not dispose of the state action limitations on the fourteenth amendment which the Civil Rights Cases and its predecessors formulated. It is equally clear that state action appeared to present no immediate problem for the results in South Carolina and Morgan. On a quite different level, however, these cases coupled with the landmark decision of United States $v$. Guest ${ }^{155}$ reformulated the state action concept, at least whenever a congressional statute is involved, into the more positive concept of a right to the enjoyment of the performance of a state's duty under the Civil War amendments, equally free from state aggression or inattention and from private interference with the right-duty relationship. ${ }^{1.46}$

The starting point for any analysis of this shift in emphasis from an essentially negative idea of violative state action to the positive concept of affirmative state duty must be United States $v$. Hall, ${ }^{1,7}$ which, as shown earlier, articulated a theory which seems to parallel in many respects that of the 1965 Term decisions. It has been argued strenuously that the idea of a positive state duty was never lost in subsequent cases, ${ }^{148}$ but, as the foregoing treatment of alternative

\footnotetext{
1042 U.S.C. $\$ \$ 2000$ a to 2000 a-6 (1964).

iwNote, however, that other aspects of the Civil Rights Act of 1964 that do not turn upon questions of race are not necessarily solvable by reliance on the thirteenth amendment, but must seek their authority under the non-racially limited fourtenth amendment.

its 383 U.S. 745 (1966).

"See Cox, supra note 9, at 93.

1726 F. Cas. 79. No. 15.282 (C.C.S.D. Ala. 1871). See note 44 supra and accompanying text.

14s See notes $41-43$ supra and accompanying text.
} 
judicial techniques illustrates, any judicial recognition of such a concept was certainly obscured, and the black victims of these decisions surely drew small comfort from the fact that these statutes were overturned on one ground instead of another. A fuller description of the process of decision which mislaid the duty concept would focus attention upon a rather singular presumption that the states were adequately and fully performing their duties under the amendments. Thus, in Rives the Court indulged the presumption that the state courts would correct a judge's exclusion of Negroes from jury panels in contravention of state law and therefore denied resort to the federal removal statute. ${ }^{19}$ In another era such a holding correctly could be attributed to due respect for the federal system; ${ }^{150}$ at a time when Congress was acting to strike down the Black Codes and legislating against rampant vigilanteism, ${ }^{151}$ the ruling seems at least bizarre. The Civil Rights Cases took this presumption to an extreme, ${ }^{152}$ for Mr. Justice Bradley's assumption of state redress not only violated impressive contrary evidence, but under the circumstances of the day the evidence should have given rise to the opposite assumption as a matter of judicial notice.

The legacy left by the Civil Rights Cases in their presumption of duty performance was felt in a series of decisions around the turn of the century. The victim in Ex parte Riggins ${ }^{153}$ was a Negro who was taken from the custody of an Alabama sheriff and the state National Guard and lynched by a mob. The defense stressed the fact that no complaint was made as to the state laws or the manner of their enforcement and asserted that the state was without fault. The district court was unimpressed and responded that the duty of the state to provide due process of law is subject to national supervision.

The other phase of the power concerns the protection of the rights which the amendment gives, though the state may not be at fault, and the power of Congress to aid the state in the performance of its duty, by removing obstruction or resistance, by private lawlessness; to the successful performance of the duty. ${ }^{154}$

\footnotetext{
1" Virginia v. Rives, 100 U.S. 313,319 (1879). See note 71 supra and accompanying text.

${ }^{150}$ The current removal statute, 28 U.S.C. \$ $1443(1)(1964)$, is still a limited device. S't'. c.g.. City of Greenwood v. Peacock, 384 U.S. 808 (1966); Georgia v. Rachel, 384 U.S. 780 (1966).

${ }^{131}$ See Kohl, supra note I, at 278-99.

152109 U.S. at 24.

15134 F. 404 (C.C.N.D. Ala. 1904).

$12 / d$. at 409.
} 
The court limited its views to the Due Process Clause, refusing to extend the duty concept to private interference with equal protection of the laws and subsequently was forced to abandon this salutary position even as to the Due Process Clause ${ }^{155}$ in light of the Supreme Court's rearticulation of the "state action only" concept in Hodges v. United States. ${ }^{156}$

The Riggins decision, however, does provide a useful steppingstone from the adamant posture of the Civil Rights Cases to the reformulated ideas of Morgan-Guest. In addition to its treatment of the scope of review issue, ${ }^{157}$ Morgan's discussion of the implementation of the Equal Protection Clause by Congress was the first major re-evaluation of the state duty concept since Riggins. Morgan in this regard cannot be understood absent a reconsideration of the main contribution of the Warren Court to the whole realm of constitutional adjudication.

As the Great Depression pointed to the need for federal power in the regulation of the economy, so did the resurgence of the civil rights movement in the 1950's create a demand for federal activity in the promotion of human rights. As the Supreme Court responded with authority for federal economic intervention by invoking the Commerce Clause, so it turned to the Bill of Rights and the Civil War amendments for the foundation of national power to deal with the infringement of civil rights. The two situations, however, are not analogous in one major respect. Those who sought economic regulation found a receptive ear in Congress and with the President; positive programs of the New Deal and of the antitrust laws of an earlier period were the initial response. The civil rights advocates, on the other hand, found little relief on Capitol Hill. Judicial response, then, was the first felt thrust of federal power. Yet, the nature of the civil rights grievances demanded more than the passive negation of discriminatory activity; it is thus small wonder that the Warren Court should be dubbed as "judicial activists."

Archibald Cox has observed that expanding notions of equal protection have imposed affirmative obligations on state governments which cannot be satisfied by inaction and that the recognition by the judiciary of this positive duty has set at large a

\footnotetext{
is United States v. Powell, 151 F. 648 (C.C.N.D. Ala. 1907). 1s.203 U.S. 1 (1906).

trs See text accompanying notes 132-39. supra.
} 
new creative force in constitutional law: $:^{158}$ a reactivated Congress better equipped than the judiciary to formulate affirmative programs and remedies responsive to positive governmental duties. An understanding of the historical context of the 1966 decisions should correct the misconception that these cases were $s u b$ silentio abandoning the "state action" standard. Abandonment is hardly the correct word for the processs. The 1966 decisions suggest that whatever the validity of the "state action" concept when judicial adjudication is invoked by private parties, the same concept cannot rigidly be applied to restrict the-legislative power of Congress. One reason for the difference in treatment has already been examined - that congressional prouncements on an issue will be treated with considerable deference, even though the Court might be inclined to reach a different decision when it has the initial judgment. ${ }^{139}$ Secondly, the changing idea that government, state and national, will be held to affirmative duties ${ }^{180}$ has caused a shift in emphasis in constitutional interpretation, away from freedom from aggressive state interference with constitutional rights to a right to governmental action which is designed to foster enjoyment of human freedoms. ${ }^{161}$ If the current and older approaches differ, it is not because one is right and the other wrong in interpreting the language of the amendments, but because each was motivated by differing concepts of the role of government in society.

Katzenbach v. Morgan is a remarkable example of the currently prevailing view. The Court chose to uphold the literacy test ban as to New York's Puerto Rican population not upon the fifteenth amendment basis which was employed in the South Carolina decision, but upon fourteenth amendment grounds. ${ }^{122}$ The decision, however, suggests a great deal more than that Congress is empowered under section 5 to determine that the literacy test itself

\footnotetext{
${ }^{13 x}$ Cox, supra note 9, at 92-93.

${ }^{15}$ See text accompanying notes $118-41$ supra.

160The affirmative obligations upon state governments to desegregate schools and to reapportion legislatures were new in the field of civil rights but not unique in the evaluation of government's role in society. Consider the Employment Act of 1946, 15 U.S.C. \$1021 (1964), which affirmed 'the continuing policy and responsibility of the Federal Government . . to promote maximum employment, production, and purchasing power."Id. See generall!. Alfange. Congressional Ponter and Constitutional Lintiations. 18 J. PUB. L. 103, 121 (1969); Miller, Toward a Concupt o/ Constitutional Dut!: 1968 Sup. Cr. Rev. 199.

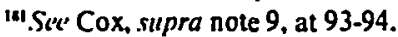

102384 U.S. at 650-61.
} 
is violative of equal protection of the laws. Such a decision adds little to what was said in South Carolina as to scope of review. The holding in Morgan is more complex and more meaningful as to the question of state action. The statute is well adapted to enforcing New York's duty to provide equal protection under the $M c C u l l o c h$. standard in that the nullification of literacy requirements allows the broadening of the political power base for those people affected, which enables the Puerto Rican community to have a greater voice in demanding equal treatment in securing access to state services and facilities. ${ }^{163}$ The equal protection duty of New York is that the state must not discriminate in providing services, if it provides them at all, and Morgan reasons that the ban on literacy tests aids the Puerto Rican community in securing state compliance with this duty. Such a holding makes more meaningful the congressional power to evaluate the effectiveness of these means of extracting state duty compliance and to weigh the relative importance of a conflicting state interest in the literacy of its electorate. ${ }^{164}$ lt also heightens the impact of the dissenters' assertion that Morgan confers upon Congress the power to determine the substantive scope of the amendment and when and how it is to be applied. ${ }^{165}$

If the Morgan case is read as suggested above, there is little reason to be surprised at the assertion in United States $v$. Guest that congressional enforcement power under the fourteenth amendment can reach all conspiracies, with or without "state action," against rights protected by the amendment. ${ }^{165}$ The choice of words in the Clark opinion in Guest, however, is perhaps unfortunate, for it leads to the conclusion that any reference to "state action" is abandoned. The facts of both Morgan and Guest suggest that this is not precisely true. The casual reader of Morgan is untroubled by the state action requirement in that case since the congressional act directly strikes down a state statute, but the state involvement which should be scrutinized is not the New York statute but the state's duty to provide services on an equal basis. ${ }^{107}$ The statute falls simply because it is an obstacle to the satisfactory fulfillment of this duty.

10. Id. at $652-53$.

is/d. at 653 .

110 /d. at 668 (dissenting opinion).

Im383 U.S. at762 (Clark, J., joined by fortas \& Black, JJ., concurring); id. at 777 (Brennan.

J.. joined by Warren, C.J. \& Douglas, J., concurring in part and dissenting in part).

${ }^{17 T}$ See note 164 supra and accompanying text. 
Guest seems to suggest that the identical result would follow if the obstacle to state duty performance was not a statute but a private conspiracy.

Once the Warren Court began to extract affirmative action from state governments in the area of human rights, it was then but a short step to recognize what had long been upheld in other contexts, ${ }^{168}$ that any transgressions by third parties upon the rightduty relationship delineated by the Civil War amendments would be subjected to federal authority. ${ }^{168}$ In Guest, Colonel Penn was seen by at least six members of the Court to be a party in such a relationship with the state of Georgia. ${ }^{170}$ lmplicit in the reasoning of these justices is the notion that the victim of a racist murder had a constitutional right to expect equal access to state facilities in Georgia and to safe passage under the equal protection of the laws in his travels through that state. Although no private conspiracy to prevent the Colonel from full enjoyment of those rights could directly violate the state's duty to provide equal access and treatment, such private action could frustrate the state's effectuation of that duty. ${ }^{171}$ Section 5 of the fourteenth amendment, therefore, could prohibit such interference as a proper exercise of congressional power to aid the state in fulfilling its obligation.

A numerical majority of the Supreme Court in Guest, then, arguably has written into law the shift in attitude of the Court away from narrowly restricted notions of state governmental duties and responsibilities to an affirmation of these duties which will be encouraged and facilitated under the auspices of congressional power.

[Section] 5 of the Fourteenth Amendment appears as a positive grant of legislative power, authorizing Congress to exercise its discretion in fashioning remedies to achieve civil and political equality for all citizens. . . I can find

\footnotetext{
IxIt has been established that private interference with the state in its perlormance of its fourteenth amendment duty is punishable under federal law. Sict. c.g.. Bullock v. United States, 265 F.2d 683 (6th Cir.), c(rrl. d'nicd. 360 U.S. 909 (1959): Kasper v. Brittain, 245 F.2d 92 (6th Cir.), curr. demied. 355 U.S. 834 (1957); Brewer v. Hoxie School Dist. No. 46.

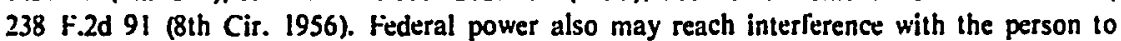
whom a governmental duty is owed in a right-duty relationship with the lederal government itself. Suc. s.g.. Logan v. United States, 144 U.S. 263 (1892); United States v. Waddell, 112 U.S. 76 (1884).

im Cox, supra note 9. at 112-13.

insee note 166 supra.

"1"See Cox, supra note 9, at 113 n.116. where the author likens the constitutional wrong to the common law idea of wrongful interference with a contractual relation.
} 
no principle of federalism nor word of the Constitution that denies Congress power to determine that in order adequately to protect the right to equal utilization of state facilities, it is also appropriate to punish other individuals-not state of ficers themselves and not acting in concert with state officers-who engage in the same brutal conduct for the same misguided purpose. ${ }^{172}$

\section{The Limits of the Congressional Enforcement Power}

1 don't see how the Constitution can last, if Katzenbach $v$. Morgan is a proper interpretation of the Fourteenth Amendment. 1 think the Constitution is dead.

Senator Sam J. Ervin, Jr..$^{173}$

Response to the 1965 Term decisions was not uniformly favorable. Many of the Supreme Court's strongest critics were among the first to realize the awesome dimensions of the congressional authority which the enforcement power cases had sanctioned. An extraordinarily narrow scope of judicial review, an expansive attitude toward statutory construction, coupled with a reformulation of the state action requirement, are the main elements that suggest that breadth of the new authority. Thus, under Alfred Mayer the logical cxtension of the Court's position would imply judicial approval of any measures designed to eliminate racial discrimination. ${ }^{174}$ More generally, Morgan-Guest would compel the courts to defer to congressional judgment in identifying the relevant fourteenth amendment relationship or state duty and in prescribing the appropriate remedy for interference, private or governmental, with the state's obligations. ${ }^{175}$

The suggestion has been made that the withdrawal of judicial restraints upon congressional legislation in accordance with the foregoing rationale would permit legislation of almost any conceivable kind, so long as it tended to enhance the fuller enjoyment of human rights. ${ }^{176}$ Archibald Cox developed a compelling argument for the enforceability of federal open housing laws two

\footnotetext{
172383 U.S. at 784.

"m Hearings on "The Supremc (iourt" Before the Subcomm. on Stparation of Poncrs of the Senatc Comm. on the Judiciary. 90th Cong., 2d Sess. 38 (1968) (remarks of Senator Ervin) [hereinafter cited as Supreme Court Hearings].

i"See notes 114-16 supra and accompanying text.

${ }^{175}$ See notes 118-44 supra and accompanying text. See also Cox, supra note 9, at 117-18; Comment, The Fourte'nth Amendment. Congressional Poner. and Private Diserimination: L'nited States v. Guest. 14 U.C.L.A.L. Rev. 553, 569-80 (1967).

"Cox, supra note 9.
} 
years before the 1968 legislation ${ }^{177}$ was enacted or the 1866 statute had been rediscovered. ${ }^{178}$ Other suggestions are that the Civil War a mendments a mply establish the power of Congress to lower statutorily the voting age nationally to 18 years of age and eliminate all literacy tests and residency requirements. ${ }^{179}$ More aggressive measures could be taken to compel school desegregation, surch as to reduce the withholding not only of federal monies from footdragging school districts, but state and local funds as well. ${ }^{180}$ This reasoning need not be restricted to matters of equal protection, for due process of law is also a section 1 duty upon state governments. There is little cause to expect that a uniform state code of criminal procedure, for example, could not be adopted to secure state compliance with federal standards of procedural due process. ${ }^{181}$ The observation has even been made that there is enough authority completely to eliminate states as governmental units. ${ }^{182}$

Obviously, at some point the Supreme Court would be forced to call a halt, to utter the magic words of Marbury ${ }^{183}$ and regain the final authority for constitutional government. Where the line should be drawn is a difficult question.

The foregoing reasoning logically extends to the conclusion that Congress has the power to deal with the "whole domain of rights appertaining to life, liberty and property, defining them and providing for their vindication," .which Justice Bradley thought the fourteenth amendment must withhold because it "would be to make Congress take the place of the State legislatures and to supercede them." Possibly the answer to the logic is that which Justice Holmes gave to a too-logical application of Chief Justice Marshall's observation that the power to tax involves the power to destroy-"not . . . while this Court sits."

\footnotetext{
"Civil Rights Act of 1968, 82 Stat. 73 (1969 U.S. CODE CONG. \& AD. NEws 89). For examples of the analysis given the 1968 legislation, see Smedley, A Comparative Anal.:sis of Tille VIIl and Section 1982. 22 VAND. L. Rev. 459 (1969); Comment. The Fiedcral Fiair Housing Requirements: Title VIIl of the 1968 (ivil Rights .Act. 1969 DUKE L.J. 733.

${ }^{17 x}$ Cox, supra note 9. at 119-21.

mId. at 107; Supreme (ourt Huarings 165 (remarks of Prof. William W. Van Alstyne).

'-Supreme Court Hearings 165.

'xi Cox, supra note 9.

${ }^{1 \times 2}$ Comment. 14th .Imendment finforctement and Congressional Power to . Abolish the States. 55 Calif. L. Rev. 293 (1967).

${ }^{10}$ Marbury v. Madison, 5 U.S. (I Cranch) 137 (1803). The original understanding of the judicial power to review congressional enactments and declare them void for constitutional reasons has recently been rearticulated, Van Alstyne. Af Critical Guide io Marhury i. Madison. 1969 DUKE L.J.1.

${ }^{\text {Im }}$ Cox, supra note 9, at 118.
} 
However, there are other answers to the fear of rampant congressional activity and the vision of a crumbling federal system. First, "the possession of congressional power should not be confused with its exercise." 185 No responsible suggestion has ever been made that the Congress has exhausted its power under the Commerce Clause, ${ }^{186}$ even though the potential power to control the economy exists, from public ownership down to the regulation of Ollie McClung's Barbeque. ${ }^{187}$ Nor is it reasonable to expect a greater exhaustion of authority to take place under the enforcement sections such that the Court would feel it incumbent to delimit tighter restrictions. Congress plays its own role in interpreting the Constitution each time it legislates, and its responsiveness to pressures of local constituents supplies an even more spirited devotion to notions of federalism. ${ }^{188}$ The solution to overly zealous nationalization of civil rights protection is appropriately with the election process, a democratic norm to which the judiciary is far less susceptible. ${ }^{189}$

More likely to be explored, at a time when the Supreme Court's rulings in some cases are under continuous public attack, is the possibility that Congress might use its power to restrict or remove established judicial principles of civil rights protection. ${ }^{190}$ The authority of Congress to dilute civil rights standards has not been litigated, and there is some suggestion that if the fourteenth is primarily a congressional power amendment, its interpretation by the legislative branch must be a two-way street. ${ }^{191}$ This suggestion by the minority in the Morgan case, ${ }^{192}$ however, was met with a gratuitous opinion by Mr. Justice Brennan that the dilution power poses another question entirely:

We emphasize that Congress' power under $\S 5$ is limited to adopting measures to enforce the guarantees of the Amendment; $\$ 5$ grants Congress no power to restrict, abrogate, or dilute these guarantees. Thus, for example, an enactment authorizing the States to establish racially segregated systems

\footnotetext{
"ki Id. at 119; see Supreme (ourt Hearings 202 (remarks of Prof. Paul J. Mishkin).

ins. Sce Supreme Court Hearings 202 (remarks of Prof. Paul J. Mishkin).

${ }^{16}$ Seer. e.g. Katzenbach v. McClung. 379 U.S. 294 (1964).

ixx.Supreme Court Hearings 164 (remarks of Prof. William W. Van Alstyne).

${ }^{10}$ Cox, supra note 9, at 119.

19. Sev, e.g. Hearings Before the Subcomm. on Criminal l.ans and Procedures of the Senate Comm. on the Jidiciury. 90th Cong., 1st Sess. (1967) (references to Title 11 of the Omnibus Crime Bill).

'"Supreme (ourt Hearings 19 (remarks of Prof. Gerald Gunther).

in' Katzenbach v. Morgan, 384 U.S. 641 , 668 (1966) (Harlan, J., dissenting).
} 
of education would not be-as requircd by $\$ 5$-a measure "to enforce" the

Equal Protection Clause since that clause of its own force prohibits such state laws. ${ }^{13}$

Not only is this dictum a logical extension of the Court's analysis in Morgan, ${ }^{194}$ it is consistent with the language of the amendments themselves: the power to "enforce" conceptually entails acts designed to strengthen, invigorate, or execute with vigor. ${ }^{195}$ Dilution implies the very opposite, ${ }^{196}$ and would not comport with the intent of the framers who feared not only a recalcitrant judiciary but also a changing Congress, and who sought to bind the former with section 5 and the latter with the provisions of section $1 .{ }^{197}$ Yet resort need not be limited to the Civil War amendments, since Congress is affirmatively forbidden to act so as to diminish civil rights by the explicit provisions of the first eight amendments. ${ }^{198}$

To say that Congress has vast powers to expand judicial standards and little power to contract those standards, however, does not reach the hard case. Thus, while the Court may find ample authority to uphold the open housing legislation or to nullify overt cutbacks upon the ends sought to be served in Miranda ${ }^{199}$ and Wade, $^{200}$ less straightforward legislation ${ }^{201}$ may present considerable difficulties. In spite of the invitation in Miranda encouraging Congress to adopt equivalent protections against involuntary confessions, ${ }^{202}$ it is doubtful whether anything other than a verbal

\footnotetext{
$10 \mathrm{Jdl}$ at $651-52$ n. 10.

131.According to the conventional theory there enunciated. the Court has invalidated state statutes under the due process and equal protection clauses only when no state of facts which can reasonably be conceived would sustain them. Where that is true, a congressional effort to withdraw the protection granted by the clause would lack the foundation of a reasonably conceivable set of facts and would therefore be just as invalid as state legislation." Cox, supra note 9. at 106 n.86.

iss Webster's NeW INTERnational Dictionary (2d ed. 1935).

"Me.Se Suprene' (ourt Hecurings 166 (remarks of Prof. William W. Van Alstyne).

im See notes 29-30.snpra and accompanying text.

${ }^{13 x}$ Senator Ervin was concerned that the Court seemed to elevate the enforcement power above other sections of the Constitution rather than to accord all sections equal dignity. Suprume (ourl Hcarings 29-30. The short answer would be that the state's power to determine voting qualifications under section 2 of article $I$ and the tenth amendment is expressly modified by the fifteenth and indirectly by the fourteenth amendment. Similarly. congressional power to act under the Civil War amendments is restricted by the Bill of Rights.

in Miranda v. Arizona, 384 U.S. 436 (1966).

2m United States v. Wade, 388 U.S. 318 (1967).

mConsider the effect of Title It of the Omnibus Crime bill upon the holdings in Miranda and Walc. Sw S. REP. No. 1097. 90th Cong., 2d Sess. (1968); Alfange, supra note 160, at 118-19.

2x Miranda v. Arizona. 384 U.S. 436, 490 (1966).
} 
warning--unless it were a complete refusal to use confessions under any circumstances ${ }^{203}$-would pass judicial muster. But a different and more complex type of situation is exemplified by the exclusionary rule which is applicable in illegal search and seizure cases. Any attempt to rid the system of the practice which excludes probative evidence because tainted by a fourth amendment violation would encounter the obvious argument that dilution of protection is the intended result. However, a statute which also includes more stringent deterrents to police, such as civil and criminal liablity, to prevent them from engaging in patent "fishing expeditions," would simultaneously offer both a dilution and an expansion of civil rights. ${ }^{204}$ Judicial evaluation of both the propriety and substance of this congressional trade-off obviously would be a more difficult analytical exercise than deciding the case where only one element, expansion on contradiction, is present. ${ }^{205}$

In fact, an argument could be made that most, if not all, statutes likely to be passed under the enforcement power necessarily will entail consequences that look both ways: A statute in good faith designed to enlarge the protection of fourteenth amendment rights may do so only at the expense of similar rights in other persons..$^{206}$ Thus, many proprietors urged that public accommodations guarantees to the blacks infringed upon their privilege as individuals to choose their associates. Doubtless the congressional choice to prefer the freedom from racial discrimination rather than a decision to perpetuate racist values in truth characterized as a freedom from association may have been an easy one for the Court to aceept, but it is important to acknowledge that the fact of the preference was indeed present in both congressional deliberations and judicial acquiescence. A closer examination of the preference might be warranted in a statute which applies sanctions to those who engage in the disruption of a public speaker by heckling and related

\footnotetext{
(omparc itl. at 458 n.27 with il. at 478.

20.The exclusionary rule has been criticized as failing to serve its primary function. one of deterrence to police, and it was not until Mapp v. Ohio. 367 U.S. 643 (1961), that it was thought that the process of excluding probative evidence was a necessary evil to implement the deterrent value of the rule.

20s (ompare notes 177-81 supra and accompanying text with notes 190-97 supra and accompanying text.

Reinforcing political leverage in one group can be done only at the expense of power in another. Consider the voting rights cases in this regard. See note 179 supra and accompanying text.
} 
provocative activity. The speaker's privilege of free speech, in the clear case, is substantially impaired by disruption which is outside the definition of opposing speech, yet the punitive statute may itself constitute a chilling effect upon one who feels compelled to reply to a speech by legitimate, indeed protected, expression but who must pause to deliberate whether this activity comes within the scope of the statute.

Katzenbach v. Morgan implies that Congress is better equipped to handle the difficult questions not only of providing redress but also of identifying the particular evils. ${ }^{207}$ That case represented a contest between equal protection rights and a competing state interest, however, and whether congressional judgment will be accepted without closer judicial scrutiny when the clash is between equally "preferred" freedoms is an open question. The Supreme Court surely has not rigidly articulated the ultimate probabilities or the inevitable direction of these cases, nor is it to be criticized for not answering all questions in advance of actual controversy. What can be said with some certainty is that new doors have been opened to a three-branch partnership ${ }^{208}$ in fostering and preserving human rights where once there was only one institution bearing the load, and that the source of the enforcement power is not lacking in precedent, both in law and in the development of modern-day concepts of government. What Congress will do with its authority rests with politics, politicians, and future decisions.

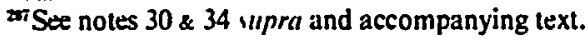

2asuprime (iourl Il'urings 36 (remarks of Prof. Gerald Gunther).
} 